\title{
Dilemas da educação na contemporaneidade: contribuições da análise do discurso
}

Débora Dainez

Faculdade de Educação, Universidade Estadual de Campinas

Resumo: este texto, tratamos de perscrutar o potencial da análise do discurso francesa com relação a problemas sociais contundentes à educação no contexto da contemporaneidade. Para isso, elegemos para a análise o fato ocorrido em uma escola pública da cidade de Realengo - RJ, em 2011, envolvendo o caso de um ex-aluno. Apresentamos como corpus de análise um conjunto de textos do Jornal Folha de São Paulo, publicados no período de 8 a 23 de abril de 2011. Atentamo-nos para como os discursos do e sobre o ex-aluno e sobre a escola aparecem na mídia, mobilizando imagens sociais e produzindo determinados efeitos de sentidos.

Palavras-chave: Educação. Escola. Linguagem. Análise do Discurso. 


\section{Dilemas de la educación en la sociedad contemporánea: contribuciones del Análisis del Discurso}

En este trabajo examinamos el potencial del Análisis del Discurso de la escuela francesa, para abordar los problemas más apremiantes de la educación en la sociedad contemporánea. Para el análisis, seleccionamos un hecho ocurrido en 2011 en una escuela pública de la ciudad de Realengo - RJ que involucra a uno de sus ex-alumnos. El corpus de datos está constituido por un conjunto de textos del periódico Folha de São Paulo, publicados entre el 8 y el 23 de abril de 2011. Prestamos atención a la forma en que los discursos sobre el ex-alumno y la escuela aparecen en los medios, movilizando ciertas imágenes sociales y produciendo determinadas efectos de sentido.

Palabras clave: Educación. Escuela. Lenguaje. Análisis del Discurso.

\section{Contemporary education dilemmas: contributions from Discourse Analysis}

In this paper we aim to search into the potential of the French discourse analysis regarding social problems which are relevant to education within the contemporary context. To do so, we have elected for our analysis the fact which took place at a public school in the city of Realengo - RJ in 2011, involving a former student of the institution. For the analysis corpus we presented a set of texts published on the newspaper "Folh de São Paulo" from April 08th to 23rd, 2011. We have focused on how the discourses from and about the ex-student and the school were presented on the media, calling for social images and producing certain sense effects.

Keywords: Education. School. Language. Discourse Analysis.

\section{Dilemmes de l'éducation dans la contemporanéité: contributions de l'analyse du discours}

Dans cet article, nous examinerons le potentiel de l'analyse du discours français par rapport aux problèmes sociaux impérieux de l'éducation dans le contexte contemporain. Pour cela, nous avons choisi d'analyser un fait ayant lieu dans une école publique de Realengo, à Rio de Janeiro, en 2011, impliquant un ancien élève. Nous présenterons comme corpus d'analyse de textes du journal Folha de São Paulo, publié dans la période du 8 au 23 avril 2011. Nous avons observé comment les discours du et sur le sujet en question, ainsi que sur l'école, apparaissent dans les médias, en mobilisant des images sociales et en produisant certains effets de sens.

Mots-clés: Éducation. École. Langage. Analyse du Discours. 


\section{Introdução}

Neste trabalho, temos como objetivo perscrutar o potencial da análise do discurso francesa com relação a questões que dizem respeito à educação e à escola no contexto da contemporaneidade. Buscamos examinar o modo como os problemas educacionais, por exemplo a violência, aparecem na mídia. Procuramos explicitar os efeitos de sentidos produzidos e apontar para a dinâmica social e as condições de produção do discurso. Para isso, trazemos para a análise o fato que ocorreu no interior de uma escola municipal da cidade de Realengo, no Rio de Janeiro - Brasil, em 7 de abril de 2011, envolvendo o caso de Wellington Oliveira, que matou 12 alunos na escola em que também foi aluno. Atentamo-nos aos discursos de/sobre o ex-aluno destacados pela mídia e para os discursos sobre a escola mobilizados de forma a recobrir o fato em questão.

Sobre o referencial da escola francesa de análise do discurso (AD) utilizado nesse estudo, Possenti (2007) considera que essa é uma perspectiva constituída por saltos, rupturas, mudanças de rumo, transformações históricas que marcam rompimentos com o modo como a linguística tem tratado os temas de pesquisa.

Se a AD não é uma ciência, é justo, mesmo assim, falar de ruptura? Creio que sim. Os movimentos de ruptura são análogos no campo científico, nos outros domínios dos saberes e também no das ideologias. Assim, contrapor a AD a outras soluções não é apenas reconhecimento do interdiscurso. Trata-se de um gesto do qual resulta produção de conhecimento. (Possenti, 2007, p.389)

Segundo Mazière (2007), por exemplo, ao contrário da gramática, que trabalha com frases, com a estrutura sintático-semântica, o discurso leva em conta o enunciado atestado, produzido de modo que os termos adotem sentido por meio de uma discursividade datada e especificada; na análise do discurso não se define o termo em uma classificação lexicográfica, mas analisa como uma interdiscursividade pode impactar o sentido do termo e, ainda, qual é o uso do termo em determinado contexto linguístico e social. Analisa-se, portanto, o sentido e os efeitos de ocorrências entre duas ou mais coordenações.

Ela [análise do discurso] não separa o enunciado nem de sua estrutura linguística, nem de suas condições de produção, de suas condições históricas e políticas, nem das interações subjetivas. Ela dá suas próprias regras de leitura, visando permitir uma interpretação. (Mazière, 2007, p.13) 
Como é possível observar, ao mudar a forma de olhar e conceber a língua, o sujeito, a conjuntura social, focalizando a história na análise, muda a maneira de proceder e, com isso, novas problemáticas e possibilidades analíticas são introduzidas.

Um importante autor que marca a história dos estudos sobre o discurso e que referimos aqui é Michel Pêcheux. Maldidier (2003), em seu trabalho sobre a releitura desse autor hoje, pondera que o discurso nessa teoria não é um objeto empírico; configura-se como um lugar teórico em que se condensam as preocupações do autor sobre a língua, a história e o sujeito. Essa conjuntura nasceu da articulação entre a linguística (língua em funcionamento e em uso), o materialismo (as marcas da história e da ideologia) e a psicanálise (a ideia de não controle do dizer).

Pêcheux (2010a) mostra que para estudar o discurso e compreender a dinâmica da sociedade é preciso analisar a formação econômica, pois é através dela que se torna possível explicar as formações sociais, as quais produzem ao mesmo tempo em que se justificam nas formações ideológicas. A ideologia fornece uma relação imaginária com o mundo, naturalizando fatos históricos. Por sua vez, as formações ideológicas se materializam, resultam em formações discursivas, região essa que determina o que (não) pode e (não) deve ser dito. Portanto, o discurso representa, expressa a relação imaginária que o sujeito tem com a sociedade, a posição que ocupa dentro dela.

Através de preocupações com o método e com o estatuto do sujeito na linguagem, Pêcheux (2010a) ancora a noção de discurso na instância da história e da ideologia, buscando apreender como no linguístico inscrevem-se as condições sócio-históricas de produção. Em suas palavras, discurso "não se trata necessariamente de uma transmissão de informações entre $A$ e $B$, mas, de modo mais geral, de um 'efeito de sentido' entre os pontos A e B" (Pêcheux, 2010a, p.81). Dessa forma, o discurso pode ser entendido como o sentido do que é dito, gerando efeitos entre locutores.

Na obra "Semântica e discurso: uma crítica à afirmação do óbvio", Pêcheux (2009) defende que o sentido de uma palavra, de uma proposição, não está fixado a priori, e tampouco pode ser qualquer um. O sentido é determinado pelas posições ideológicas presentes no processo histórico em que os enunciados são produzidos. Logo, a ideologia, para Pêcheux, é a matriz do sentido.

Ao tratar a relação da AD com as estruturas de uma língua, Possenti (2009), de acordo com Pêcheux, reafirma que essas estruturas são o lugar material em que se dão os efeitos de sentidos. Um discurso reproduzido na fala de um sujeito posicionado é, simultaneamente, resultado das determinações da língua e de um processo histórico específico, que fazem com que se produza dada sequência discursiva. Assim, é analisando o discurso que se torna possível observar a relação entre língua, ideologia, 
sujeito e história inscrita em uma memória discursiva.

Por memória discursiva, Pêcheux (2010b) entende que essa

[...] não poderia ser concebida como uma esfera plena, cujas bordas seriam transcendentais históricos e cujo conteúdo seria um sentido homogêneo, acumulado ao modo de um reservatório: é necessariamente um espaço móvel de divisões, de disjunções, de deslocamentos e de retomadas, de conflitos de regularização... Um espaço de desdobramento, réplica, polêmicas e contra-discursos. (Pêcheux, 2010b, p.56)

É necessário destacar aqui as contribuições de outros estudos sobre a relação memória e discurso. Mencionamos a colaboração de Achard (2010), que analisa o papel da memória no discurso e, por seguinte, o estatuto dos implícitos. O argumento do autor é que a estruturação do discursivo constitui a materialidade de uma memória social e, com isso, apresenta a memória inscrita na circulação do discurso. $O$ implícito, segundo o autor, trabalha sobre a base de um imaginário que o representa como memorizado, como conhecimento aprendido por alguém que lê. Neste caso, destaca-se a relação memória e imaginário no discurso, sendo que o implícito faz parte do imaginário sem, necessariamente, ter sido proferido e pode ser recuperado.

A memória para Achard (2010) é tida como regulação e não repetição; regulação situada entre o histórico e o linguístico, que se apoia, necessariamente, sobre o que é conhecido. A memória, então, não restitui frases escutadas no passado, mas julgamentos sobre o que é reconstruído discursivamente. Assim, trabalhar com a memória é regularizar o discurso e recuperar os implícitos, sendo esse um meio de sentido do enunciado.

Outra posição é o trabalho de Davallon (2010), que concebe a imagem e o som como uma operação de memória social. Segundo ele, com o aparecimento da imprensa, o desenvolvimento dos meios de registros da imagem e do som são fatores que deslocam a questão da memória social que não se encontra mais nos indivíduos, mas nas mídias. A memória, nesse sentido, é o que se lembra. É pertinente notar o contraponto do trabalho de Orlandi (2010) que, ao compreender a relação entre memória e a situação de censura, argumenta que a memória é feita de esquecimentos, de silêncios, de sentidos não ditos, de sentidos a não dizer. $\mathrm{O}$ acontecimento que escapa à inscrição da memória é, justamente, aquele que comporta sentidos que devem ser evitados. Nem tudo é possível de ser dito em dada conjuntura social. A ideia de memória está relacionada, para essa autora, à ideia de interdiscurso. "Ela [memória] se constitui pelo já-dito que possibilita todo dizer" (Orlandi, 2010, p.64). Assim, o sujeito é historicamente determinado pela memória do dizer. Esse modo 
de proceder está relacionado com a seguinte tese apresentada por Pêcheux (2009), que se refere ao pré-construído: algo fala sempre antes e em outro lugar. Assim, o dizer pressupõe um já dito.

Como é possível perceber, os conceitos de interdiscurso, de memória discursiva, de implícitos, de efeitos de sentidos, de formações discursivas, ancoram-se na íntima relação entre discurso, história, ideologia e sujeito, configurando como ferramentas para uma possível compreensão sobre como a circunstância social e histórica e os mecanismos da língua se imbricam no processo discursivo; em outras palavras, permite-nos indagar sobre o porquê, em dadas condições de produção, o falante enuncia determinado enunciado.

A partir desse referencial teórico, apresentamos como corpus discursivo de análise, ou, conforme a definição de Courtine (2009), a formação de um conjunto de sequências discursivas estruturado de acordo com as condições de produção do discurso, um conjunto de textos que comportam várias seções do Jornal Folha de São Paulo e que tratam do fato já citado. Os textos analisados se referem a notícias, entrevistas, cartas de leitores e artigos de opinião do referido jornal, publicados no período de 8 a 23 de abril. Com isso, objetivamos no critério de seleção desse conjunto de artigos a formação de um corpus heterogêneo e polêmico, contendo diferentes posições com diversas opiniões para dar conta de um processo discursivo.

Seguimos, assim, indagando sobre como os conceitos e as discussões desse campo do conhecimento, Análise do Discurso Francesa, nos ajudam a enxergar analiticamente problemas sociais concernentes ao campo da educação.

\section{Discursos de/sobre um ex-aluno: posições discursivas em tensão na constituição de um acontecimento no interior da escola}

No dia 7 de abril de 2011, Wellington Oliveira, 23 anos, matou 12 crianças em uma escola municipal na qual foi aluno e, em seguida, suicidou-se (o fato esteve em evidência na mídia do dia 8 a 23 de abril de 2011, conforme já dito, período referente aos textos trabalhado neste estudo). Temos aqui um fato circunscrito, pontual - matou na escola e depois de matar se matou - que repercute socialmente, mobilizando uma massa discursiva. Indagamos: O que foi possível de ser dito, o que é permitido que fosse dito e quem pôde dizer o que, em dado momento, no interior de determinada conjuntura social? 
A primeira chamada do jornal, num dia depois do fato, foi "Ex-aluno mata 12 estudantes, na pior tragédia em escolas do país". Com base na análise de Pêcheux (2010a), operamos de modo a transformar esse discurso para chegar aos enunciados, ou melhor, tomar o texto de uma superfície linguística e dizer de outra maneira, a fim de remontar para encontrar os implícitos. O caso diz respeito a uma tragédia. Houve morte. Doze estudantes morreram. Quem matou foi um ex-aluno da escola. Aconteceu em uma escola brasileira. Foi a pior tragédia envolvendo escolas no país. Os implícitos que trazem um efeito de memória, de um já dito em outro lugar são: a marca do lugar de quem foi aluno e não é mais - Wellington foi aluno da mesma escola em que matou 12 alunos; o lugar específico no Brasil onde acontece o fato, no Estado do Rio de Janeiro, considerado um Estado violento no país; faz alusão a outras tragédias que podem ter ocorrido recentemente; propõe que já houve violência dentro da escola, embora, nesse caso tenha sido a mais intensa, devido ao número de mortes. Implícitos esses que inferem a questão de segurança pública no país, mais especificamente, no estado do Rio de Janeiro e dentro de uma escola pública.

Unidades lexicais como "tragédia", "chacina", "massacre", "barbárie", "atentado" são usadas e se repetem nos temas que se referem aos textos de noticiários, reportagens. Essas palavras designam e nomeiam, ou seja, servem como interpretante para uma situação específica, indicando o sentido de um estado de violência extrema no país que nunca havia acontecido dessa forma, com tamanha proporção.

"Agora somos, de fato, um país violento e de loucos também" (Painel do Leitor). Esse enunciado remete a um já dito, de que, antes desse fato acontecer, já éramos um país violento, conforme vimos também acima. Reitera a ocorrência de outras situações de violência e que esse fato vem a comprovar que o Brasil é um país violento, que o Rio de Janeiro é um Estado violento e que falta segurança nas escolas, mas não só, comprova também a existência de loucos no país. O que está subentendido é a falta ou a fragilidade de segurança pública que pode ser irrompida, permitindo a violência, sendo que essa está associada provavelmente a um estado de loucura.

"Que o rapaz assassino tinha transtornos mentais, é óbvio" (Artigo de Opinião). O fato de Wellington ter problemas mentais é afirmado incisivamente e garantido pela expressão "é óbvio", impossibilitando, assim, o questionamento da ideia e que haja outras explicações.

Discursos do campo de segurança pública (relacionados aos termos violento, assassino) e do campo da psiquiatria (palavras como loucos, transtorno mental) sustentam-se um no outro no funcionamento discursivo, o que, provavelmente, pode gerar efeitos de que todo doente mental é violento ou todo assassino é doente mental. Historicamente, aquele que foge ao padrão esperado socialmente é tido 
como o louco e, discursivamente, segundo Foucault (2010), vai sendo concebido como indivíduo perigoso, ou seja, um indivíduo que rompe com as regras jurídicas e com certa normalidade psicológica, diferindo-se pelo comportamento e conduta, colocando a vida do outro em situação de risco.

Estereótipos como "assassino, adotivo, louco, psicopata, retardado, esquisito, animal", vão sendo usados para nomear Wellington. $O$ trabalho com os estereótipos nos textos que recobrem as falas dos colegas, familiares de Wellington, vizinhos, especialistas é a condição da manutenção deles. "O assassino", "O louco", em vez de falar Wellington, funciona como um pré-construído, objeto dado pela história, que conota e designa certo estado do indivíduo, dado como objeto natural, isto é, quem mata e comete um crime é um assassino; o fato de ser adotivo pressupõe que ele foi rejeitado pelos pais e isso pode levá-lo a ser um indivíduo revoltado; quem age de forma inesperada e indesejada é louco, esquisito; aquele que não é eficiente é deficiente, retardado; por não saber viver em sociedade, não respeitar as regras sociais e, portanto, não ser civilizado e ter uma atitude imoral, é selvagem, animal.

"Na escola não jogava futebol com os colegas, não compareceu à própria festa de formatura de 8 a série e nunca foi visto com namorada". "Era antissocial". (...). "Aos 23 anos, sua experiência profissional era mínima. Foi 'auxiliar de serviços gerais' - pouco mais que um encarregado de limpeza - numa indústria de produtos alimentícios. Levou dois anos para ser promovido a auxiliar de almoxarifado, de onde foi demitido por baixa produtividade" (Artigo de Opinião).

Por oposição, marcada pelo uso da palavra "não", vai se mostrando o que a sociedade esperava do ser aluno, do ser profissional, do ser cidadão Wellington. Esperava que ele jogasse futebol, namorasse, participasse da formatura, tivesse muitos amigos, fosse produtivo no trabalho, progredisse de cargo. No enunciado acima, que diz respeito à relação de Wellington no/com o trabalho, a expressão "pouco mais que" mobiliza a questão do valor do emprego a partir de uma dada hierarquia social, a desvalorização de certas atividades e, portanto, a desvalorização dos sujeitos que a realizam. No enunciado - "Levou dois anos para ser promovido a auxiliar de almoxarifado" - o que aparece como pressuposto é a cobrança de certo tempo esperado para a promoção de cargo, ou seja, presume-se que um bom trabalhador ascenda de cargo mais rapidamente, em menos de dois anos. Esses dizeres marcam as imagens de trabalho e a desconsideração das condições concretas de qualquer emprego, a imagem social sobre o que é ser um jovem empreendedor e bem-sucedido no mercado de trabalho.

Para distinguir o lugar de Wellington nesse acontecimento, as crianças que morreram são apresentadas no jornal pelas características positivas, pelas qualidades e planos, projetos futuros - "sonhava em ser modelo"; "costumava ajudar a avó a arrumar a 
casa"; "era uma menina alegre, cercada de amigos"; "planejava estudar na marinha"; "queria ser jogador de futebol"; "queria começar a trabalhar o quanto antes". A ação de Wellington também é posta em relação contrária à "ação heroica do Sargento Alves" como exaltam o governador do Estado do Rio de Janeiro e o prefeito da cidade na época, em entrevista ao Jornal Folha; está implicada a dicotomia entre o bem e o mal, o certo e o errado, a lei e o fora da lei.

Especialistas da área de educação e da saúde se manifestam e explicam cientificamente, falam por meio das teorias e a partir do lugar de autoridade ocupado socialmente. Dizeres legitimados que produzem efeitos de veridicidade.

"Ataques têm a ver com bullying", afirma um especialista em violência escolar. E considera que se trata de um "retorno dessa memória na mente distorcida".

"O bullying pode ser gatilho importante para uma doença psiquiátrica", observa um professor e médico psiquiatra em uma entrevista com o jornal, e define que "No caso do Rio, há indícios de que é um caso de esquizofrenia". Ainda, esclarece que "Os alvos de bullying normalmente são crianças tímidas, desajeitadas, com autoestima baixa e com dificuldade de se defender".

Os dizeres do especialista do campo educacional e do especialista do campo da saúde se relacionam quando definem o caso pela existência associada do bullying e do problema mental, ou seja, determinam que Wellington foi vítima de bullying, mas não é só esse o motivo que explica sua atitude. Sugerem que ele também tem um problema psíquico. No entanto, o enunciado do especialista em educação - "O retorno dessa memória na mente distorcida" - deixa implícito que Wellington já tinha uma alteração mental independente de ter ou não sofrido o bullying. Já o enunciado do especialista em psiquiatria - "O bullying pode ser gatilho importante para uma doença psiquiátrica" - indica que o bullying pode ser a causa de um problema mental. O que causou o quê? A doença mental foi a causa ou a consequência de o garoto ter sofrido o bullying?

Ao mesmo tempo em que os discursos se entrecruzam e se ancoram um ao outro, negam-se pelos modos diferentes como concebem e explicam a ocorrência. A noção de interdiscurso apresentada por Maingueneau (2008) possibilita compreender como um determinado discurso remete a outro, frente ao qual é uma resposta direta ou do qual ele orquestra os termos principais, reitera alguns argumentos, incorpora elementos ou anula, contrapõe-se a outros. Como defende o autor, cada discurso introduz o "Outro" em seu fechamento que se encontra na raiz de um "Mesmo" já descentrado em relação a si próprio. Em outras palavras, conforme Possenti (2009) apresenta a noção de interdiscurso discutida por Maingueneau, "o Outro é o que faz 
sistematicamente falta a um discurso, é aquela parte de sentido que foi necessário que o discurso sacrificasse para constituir sua identidade" (Possenti, 2009, p.164).

O diagnóstico de uma possível esquizofrenia e a definição de características das pessoas que podem vir a sofrer o bullying são aspectos proferidos no discurso do psiquiatra, um locutor representativo do assunto, ou seja, ocupa uma posição que o autoriza a detectar o desvio, classificar o problema através de um diagnóstico e fazer um prognóstico.

Um colega que estudava com Wellington diz: "Nós que devíamos ter morrido. Não era para ninguém ter pago por uma coisa que nós fizemos". O jovem, ao usar a primeira pessoa do plural, não fala só por si. Esse "nós", que tem como pressuposto uma ação realizada por um grupo, evoca uma memória discursiva sobre o bullying como uma prática exercida em grupo de colegas cujo alvo é uma vítima. Fica implícito que fizeram algo socialmente não aceitável. Outro implícito é a definição do ato de Wellington como vingança desencadeada pelo bullying, uma forma de expressar o que ele viveu no passado, de dar o troco. A imagem que o colega de Wellington tem de si e dos demais alunos, do próprio Wellington, está ancorada no imaginário social que designa lugares e representações sociais dominadas pelos discursos científicos do bullying. O colega de Wellington responde justamente o que se espera que ele responda diante dessa situação.

Wellington escreve em uma carta antes do acontecimento "Não sou eu o responsável pela morte de todos. A culpa é dos que se aproveitam da bondade ou da inocência de um ser". Prevê a tragédia, antecipa a morte das crianças e se isenta da culpa. De acordo com Pêcheux (2010a), as condições e as posições ideológicas levam o sujeito a agir discursivamente de determinado modo. Em outras palavras, o sujeito é levado a dizer por um processo de interpelação, no interior de uma determinada formação discursiva. A tese de Althusser (1974) de que a ideologia interpela indivíduos como sujeitos, é lembrada por Pêcheux (2010a). Sujeito no discurso que fala reúne, em seu dizer, formações imaginárias dos desamparados, inocentes que sofrem bullying, e dos quais ele assume a causa pela experiência de vida e propõe a defender num gesto heroico sustentado nas imagens religiosas e também pela mídia contemporânea.

Wellington vai sendo representado e se representa dependendo do ponto de vista discursivo de quem vai enquadrá-lo. Sujeitos esses que não são a origem dos seus discursos, mas que falam a partir de determinada doutrina aceita.

O discurso religioso também é acionado e de modos diferentes.

O Rabino do Judaísmo prega num artigo de opinião (A tragédia de Realengo e a 
Páscoa Judaica): "Na triste tragédia da escola de Realengo, o assassino foi descrito pelos colegas como uma pessoa tímida e calada. Porém, numa análise mais profunda, percebe-se que ele cresceu sem o calor familiar necessário". O pressuposto é que a causa de Wellington ter tido determinada conduta está relacionado com o fato de ter sido abandonado pela família e não por ele ser uma pessoa tímida e calada, caracterização essa que provém do discurso psiquiátrico sobre bullying - "Os alvos de bullying normalmente são crianças tímidas, desajeitadas, retraídas". O discurso científico e o discurso religioso se chocam na explicação do ato de Wellington, na busca de uma causa.

Já o representante da União Nacional das Entidades Islâmicas, numa entrevista ao jornal, defende: "Ele não é muçulmano, não faz parte de religião nenhuma. (...). O que ele fez não tem religião". A ideia é que o ato de Wellington está fora da religião, não pertence a esse campo. O implícito é que ele é ateu, não tem uma crença num Deus.

Esse acontecimento histórico e discursivo vai sendo produzido no interior de uma formação que ancora uma heterogeneidade de discursos, em outras palavras, um modo historicamente produzido que constitui uma memória discursiva. Os problemas de educação, de saúde e de segurança pública são explicitados na análise ao mesmo tempo em que se misturam numa rede de discursos proferidos na mídia. $\mathrm{O}$ ato de Wellington é o núcleo dos debates que constituem esse acontecimento discursivo. Através da caracterização negativa que vai sendo feita de Wellington, a partir da qual se constrói a figura desviante, apresenta-se o tipo de pessoa ideal que mantém a ordem social, o cidadão esperado ideologicamente.

\section{Mobilização de imagens e sentidos sobre a escola pública}

"A festa pelos 40 anos da escola municipal Tasso da Silveira, em Realengo, na zona oeste do Rio, se transformou em tragédia na manhã de ontem, quando o ex-aluno Wellington Menezes de Oliveira, 23, matou dez meninas e dois meninos e feriu outros 12, num massacre sem precedentes na história brasileira" (Artigo de Reportagem).

"Palco da chacina" (Chamada do jornal referente à escola).

A evocação, no início do enunciado, sobre a possível festa comemorativa dos 40 anos de existência da escola, agudiza a intensidade do fato ocorrido, marcando a extrema oposição com o que aconteceu de fato, uma tragédia. O uso do verbo "transformou" gera um efeito discursivo que indica a mudança drástica de uma realidade, da festa 
que se torna tragédia, de um momento de comemoração à vida para um momento de dor pela morte, de um estado de alegria para um estado de tristeza, de um sentimento de orgulho e realização para um sentimento de medo, desamparo. Implícitos esses que conotam contrapontos do que foi planejado, programado e, portanto, esperado, para o que realmente aconteceu no interior de uma instituição escolar, o não esperado, um acontecimento surpreendente e impensável. Mas para quem?

O professor que presenciou a situação, ao se referir aos tiros, admite "(...) dentro da escola, foi a última coisa que pensei em ouvir na vida". De que escola se fala a partir da posição ocupada de quem a fala? Na voz do professor, tiro dentro da escola é algo inusitado. O pressuposto é que educação e esse tipo de violência não combinam.

Palavras como "tragédia, massacre, chacina" nomeiam o evento que ocorreu no interior de uma escola pública. Escola pública e tragédia são associadas, produzindo efeitos discursivos. A recorrência, nos artigos de reportagens, do uso desses termos (tragédia, massacre, chacina) produz um efeito enfático na questão da situação dentro de uma instituição escolar pública que vai assumindo uma característica de lugar degradado, problemático, que abriga violência, evocando uma memória discursiva acerca da precariedade do serviço educacional público.

Chega de violência. Paz! Amor! Eu amo essa escola! (Enunciados escritos nos muros da escola por alunos e professores dias após o fato ter ocorrido). A sentença "Chega de violência", construída de modo imperativo, gera efeito de indignação, reivindicação e protesto em relação ao que aconteceu na escola. Contudo, é uma ordem apresentada de modo indefinido, ou seja, não se dirige a ninguém especificamente, é anônimo. Os enunciados exclamatórios - "Paz! Amor! Eu amo essa escola!" - evocam a imagem de como a escola deveria ser, isto é, um espaço da percepção da consciência social, aprendizados dos valores humanos, dos bons modos e bons sentimentos, lugar que prepara para a convivência harmoniosa em sociedade. Alunos e professores, ao mesmo tempo em que reivindicam sobre a situação ocorrida, expõem a relação afetiva com a escola. O efeito que se produz é de que a escola não é a responsável pelo fato de violência, mesmo que esse evento tenha ocorrido em seu interior.

A análise vai apontando para a escola como um espaço que agrega realidades contraditórias, ou seja, um mesmo lugar se constitui discursivamente em vários lugares, a partir da posição ocupada de quem a fala (professores e alunos, textos de noticiários).

Nos enunciados que compõem os noticiários, o responsável pela situação de violência dentro da escola foi um "ex-aluno". A expressão "ex-aluno" aparece como uma forma de apresentar a relação de Wellington com a escola. O implícito é o que a posição de 
"ex" significa: familiaridade com a escola, pertença de certo modo a essa instituição. A implicação disso é o fracasso da escola em relação à formação desse cidadão pela resultante também inesperada. Assim, infere questionar sobre o que está sendo produzido dentro da escola e as consequências sociais dessa formação educativa. Essa inferência remete-se a uma formação ideológica de que a função da escola é o preparo do aluno para o exercício da cidadania, desenvolvendo bons comportamentos. Deste modo, o discurso nasce simultaneamente do que vem antes e do que acontece em determinadas condições de produção.

A análise da expressão "ex-aluno" nos faz prestar atenção na partícula "se" que precede o verbo "transformou" do primeiro enunciado (referente ao artigo de reportagem) analisado neste texto. A festa se transformou em tragédia, isto é, ela não foi transformada por um agente externo. O agente é interno, pertence de certa forma à escola. O que opera ou funciona como/no discurso é que foi a própria festa - esse estado de abertura de escola para todos, para a celebração dos 40 anos que propiciou a entrada do ex-aluno, que por ocupar essa posição na escola, quer dizer, por apresentar essa aproximação com a instituição, não cria suspeitas. Melhor dizendo, foi a escola aberta para a festa e a convocação dos alunos e ex-alunos para falarem dela, estando nela, que resulta no acontecimento. $O$ efeito que gera é que a escola produz a condição de violência dela mesma.

Um professor de escola pública comenta no painel do leitor: "Está certo que a escola deve ser aberta para todos, mas, infelizmente, nem todos estão aptos a frequentá-la". Ao considerarmos, com bases em Pêcheux (2010a), que as formações imaginárias resultam e se manifestam dos/nos processos discursivos, ressaltamos analiticamente nesse enunciado que por antecipação de possíveis objeções - "Está certo que...." - o professor marca sua opinião sobre o espaço escolar e projeta uma representação imaginária do receptor, sendo que, a partir dela, estabelece estratégias discursivas. Nessa construção argumentativa, inicia-se o enunciado considerando uma dada posição de que a escola deve estar aberta para todos, o que implica a ideia de "educação para todos", que funciona aqui como discurso transverso. Discurso esse referido em slogans, propagandas política, legislação educacional, aceito e naturalizado socialmente. A conjunção "mas" surge endossando o segundo ponto de vista que se torna argumentativamente dominante. Aparece no enunciado uma estratégia argumentativa constituída a partir de uma heterogeneidade discursiva, o discurso de um outro é colocado em cena pelo sujeito que, ao mesmo tempo, colocase em cena como um outro. Um argumento contrário é assumido primeiramente para depois inserir determinada posição discursiva defendida, qual seja a escola não deve estar aberta para todos, somente alguns estão aptos a frequentar esse espaço e fazer parte dessa instituição. Possenti (2009) discute sobre a conjunção "mas" no interior da semântica argumentativa e considera que, na terceira fase da 
análise de Ducrot, essa conjunção é analisada como simulando uma situação na qual um enunciador contrapõe seu discurso (que é argumentativamente dominante) a outro, conforme acontece no enunciado analisado. Assim, o "mas" configura, num mesmo enunciado, um efeito não consensual entre duas posições estabelecidas historicamente no interior de uma formação discursiva que se refere à relação escola e comunidade. Persiste no enunciado certa divergência ao focalizar a aproximação entre instituição escolar e sociedade.

A escola é lugar para quem? De que escola e de que aluno o professor fala? Quem pode frequentar o espaço da escola? O enunciado mobiliza imagens de escola e de aluno. Escola deveria ser aberta para todos, mas precisa ser espaço restrito e circunscrito. Nem todos são preparados para frequentá-la. O uso do termo "apto" traz o pressuposto da aptidão, competência e capacidade individual que somente alguns tipos de pessoas apresentam e em cujo padrão Wellington não se enquadra.

Wellington, em uma gravação feita antes de executar o plano, avisa sobre o que foi cuidadosamente planejado, justifica o que vai ser realizado, antecipa os efeitos do acontecimento: "Descobrirão quem eu sou de maneira mais radical, numa ação que farei pelos meus semelhantes, que são humilhados, agredidos, desrespeitados em vários locais, principalmente em escolas e colégios, pelo fato de serem diferentes". Fala do lugar de quem sofreu violência e foi discriminado, marginalizado pela diferença dentro do espaço escolar e de quem fará violência na escola. Os verbos no tempo futuro indicam uma ação que ele realizará. Wellington fala para a posterioridade, o destinatário oculto ("Descobrirão..." - Quem descobrirá?) gera um efeito discursivo que diz respeito a todas as pessoas do mundo.

O dizer de Wellington é marcado pela heterogeneidade discursiva no interior de uma mesma formação referente à legislação educacional, lugar em que o discurso sobre a igualdade de direitos e o discurso sobre o respeito à diferença são mobilizados e se ancoram um ao outro. A identidade de um discurso se constitui e se alimenta através de outros discursos, uma vez que falar é sempre falar com e por meio de outros discursos (Maingueneau, 2008). A hipótese é a de que essa relação interdiscursiva que se estabelece entre o discurso de igualdade de direitos e do discurso do respeito à diferença na fala de Wellington produz uma imagem de escola como uma instituição rígida, que não acolhe e não respeita as diferentes características dos alunos (diferentes origens sociais, diferentes modos de aprender, de participar e de se comportar, diferentes níveis de instrução), que exclui, isola, reprova, agride quem não corresponde às suas normas e padrões legitimados (corresponde ao saber inculcado, que se deve ter - saber legítimo que é valorizado; e o que e como se deve ser - a imagem de aluno ideal) dentro de uma ordem social. Aqueles que escapam, são tidos como alunos problemas, deficientes. A escola forma e produz a eficiência 
em alguns e a deficiência em outros.

O diretor da escola, no lugar de autoridade, anuncia: "As duas salas invadidas por Wellington Menezes de Oliveira não terão mais aulas. Elas serão usadas como biblioteca digital e espaço multifuncional para alunos com necessidades especiais". Reconstruindo o enunciado: As salas que um dia funcionaram como ambiente de aula, após a tragédia, terão outra finalidade. Serão utilizadas como biblioteca digital e espaço multifuncional, o que pressupõe que sejam duas salas. Quem frequentará são crianças caracterizadas como alunos com necessidades especiais. No entanto, no enunciado, há certa ambiguidade no que se refere a quem está endereçado o uso da sala que funcionará como biblioteca digital. O pré-construído é que o espaço multifuncional seja usado pelos alunos com necessidades especiais enquanto a biblioteca digital seja usada por todos os alunos. Dessa forma, não fica explícito no enunciado a quem se orienta a biblioteca digital, entretanto o pré-construído não se restringe aos alunos especiais.

O pressuposto que vai sendo marcado no discursivo é a transformação dos espaços, o apagamento da lembrança do evento, produzindo esquecimentos. Esse movimento de deslocar sentidos, apagar memórias configura novos modos de uso e funcionalidade das salas. Uma das salas, biblioteca digital, circunscreve um espaço que abre para possibilidades futuras e convoca todos os alunos para novos usos do espaço. Enquanto a outra sala é endereçada aos alunos com deficiências, o que muda também o uso e a função. Implicitamente, o lugar de aula, de ensino transforma-se no lugar de não aula e, com isso, apesar de nomear alunos com necessidades especiais, o efeito que gera é que esses sujeitos não são alunos da escola. O fato histórico e discursivo aponta para a organização da estrutura e do sistema de ensino e a mudança de funcionalidade e caráter do espaço marca o lugar da educação inclusiva dentro da educação geral. O lugar atribuído aos alunos com deficiência dentro da escola é justamente o lugar renegado, rejeitado por todos os demais. O discurso de exclusão (de um não lugar) é mobilizado e persiste no discurso da inclusão escolar que legitima a impressão de um lugar dentro da escola que se ancora em um não lugar. Aqui ressoam as políticas de educação inclusiva, mas também as imagens desses alunos com deficiências que podem não se dar conta da tragédia. Imagens de que esses alunos não entendem, não participam dos sentidos da história da escola.

A análise vai mostrando como a escola ao mesmo tempo em que é objeto de discurso -torna-se conhecida na medida em que se fala dela dentro de uma determinada conjuntura-, é a instituição - funciona como aparelho ideológico do Estado, conforme Althusser (1974)- na qual os discursos são (re)produzidos. Ou melhor, indivíduos interpelados em sujeito (professor, alunos, ex-aluno, diretor) falam da e na escola de acordo com um sistema de ideologia, a partir de posições, marcam esse lugar social 
ao mesmo tempo em que são marcados nele. Num movimento de circularidade, instaurado por dadas condições de produção, discurso e instituição vão sendo (re) constituídos historicamente, lembrando que, no discurso, as questões não se fecham, mas retornam.

\section{Algumas considerações}

Consideramos que o referencial da análise do discurso de linha francesa nos fornece uma estrutura teórica e conceitual que subsidia fecundas ferramentas analíticas para uma compreensão mais densa da dinâmica social e da produção discursiva face sua relação com uma dada formação ideológica. Viabiliza, assim, compreender como linguagem e ideologia se articulam em sua relação recíproca, pela/na qual efeitos contraditórios são gerados nos processos de significação movimentados historicamente. Assim, "analisar o discurso é fazer desaparecer e reaparecer as contradições: é mostrar o jogo que jogam entre si; é manifestar como pode exprimi-las, dar-Ihe corpo" (Foucault apud Brandão, 2004, p.51).

Essa forma de análise possibilitou-nos pensar na relação do indivíduo com a sociedade, dando visibilidades às condições de produção discursivas e seus (efeitos de) sentidos, perscrutando o (não) dito que aludiu processos sociais intimamente relacionados à educação. Imagens sociais - de aluno, de deficiência, de escola - foram mobilizadas; modos de conceber os problemas que pertencem à determinada ordem social e sua relação com a instituição escola - a violência, a discriminação, a exclusão foram explicitados. De maneira geral, vimos como os discursos que recobrem e atravessam o fato tomado para análise, historicamente situado, ora responsabilizam o indivíduo ou a história de vida do indivíduo que cometeu um ato de violência não aceito pela sociedade; ora responsabiliza os familiares, os colegas, os professores, a escola por condicionar a produção desse ato no seu interior. Contudo, oculta-se a responsabilidade da estrutura social - o meio e o modo de produção, de distribuição, de civilização -, a situação de desigualdade que gera a não perspectiva de vida.

Analisar as relações e as produções discursivas, portanto, possibilita trabalhar com a linguagem em funcionamento, condensando, carregando, expressando as marcas de dadas condições histórico-político-econômicas-sociais que incidem na constituição dos sujeitos. Nessa ótica, é possível deslocar a concepção de formação subjetiva do sentido para o sentido dimensionado no tempo e no espaço das práticas sociais, produzido na dinâmica das relações e das condições concretas. Dito de outra forma, o sentido é determinado pelas posições ideológicas mobilizadas no processo histórico e social em que as palavras são produzidas (Orlandi, 2009). Isso nos leva a compreender 
a consciência individual entretecida à consciência coletiva, ou seja, povoada da história de produção humana, de relações discursivas em conflito.

Enfim, ainda podemos considerar, como as imagens e sentidos de escola pública que incidem discursivamente esfacelam a função social dessa instituição, bem como a sua valorização enquanto espaço onde seria possível intercambiar bens culturais, produzir e compartilhar o conhecimento acumulado historicamente. Fica implícito no jogo interdiscursivo quem pertence a essa instituição e quem não pertence, quem pode fazer parte e quem não pode. A relação público e privado, a privatização do público, tensões recolocadas ao longo da história social, política e econômica das sociedades, permeiam as posições discursivas. A escola pública, espaço comum para todos, é, ao mesmo tempo, território de alguns, expressão de certa normatividade que reprova condutas discordantes.

\section{Referências}

ACHARD, Pierre. Memória e produção discursiva do sentido. In: ACHARD, Pierre. et al. (orgs.). Papel da memória. Campinas, SP: Pontes, 2010, p.11-21.

ALTHUSSER, Louis. Ideologia e aparelhos ideológicos de Estado. Lisboa: Presença, Martins Fontes, 1974.

BRANDÃO, Helena Nagamine. Introdução à análise do discurso. Campinas: Editora da UNICAMP, 2004.

COURTINE, Jean-Jacques. Análise do discurso político: o discurso comunista endereçado aos cristãos. São Carlos: EdUFSCar, 2009.

DAVALLON, Jean. A imagem, uma arte de memória? In: ACHARD, Pierre. et al. (orgs.). Papel da memória. Campinas, SP: Pontes, 2010, p.23-37.

FOUCAULT, Michel. Os anormais. São Paulo: Martins Fontes, 2010.

JORNAL FOLHA DE SÃO PAULO. Artigos publicados no período de 8 a 23 de abril de 2011.

MAINGUENEAU, Dominique. Gênese dos discursos. São Paulo: Parábola, 2008.

MALDIDIER. Denise. A inquietação do discurso: (re)ler Michel Pêcheux hoje. Campinas: Pontes, 2003. 
MAZIÈRE. Francine. A análise do discurso: história e práticas. São Paulo: Parábola Editorial, 2007.

ORLANDI, Eni de Lourdes Puccinelli. Análise de discurso: princípios e procedimentos. Campinas, SP: Pontes, 2009.

ORLANDI, Eni de Lourdes Puccinelli. Maio de 1968: os silêncios da memória. In: ACHARD, Pierre. et al. (orgs.). Papel da memória. Campinas, SP: Pontes, 2010, p.59-71.

PÊCHEUX, Michel. Por uma análise automática do discurso. Campinas, SP: Editora da Unicamp, 2010a.

PÊCHEUX, Michel. Papel da memória. In: ACHARD, Pierre. et al. (orgs.). Papel da memória. Campinas, SP: Pontes, 2010b, p.49-57.

PÊCHEUX, Michel. Semântica e Discurso. Campinas, SP: Editora da Unicamp, 2009.

POSSENTI, Sírio. Questões para analistas do discurso. São Paulo: Parábola, 2009.

POSSENTI, Sírio. Teoria do discurso: um caso de múltiplas rupturas. In: MUSSALIM, Fernanda.; BENTES, Anna Christina. (orgs.). Introdução à linguística: fundamentos epistemológicos 3. São Paulo: Cortez, 2007.

Recebido em fevereiro de 2016 Aprovado em março de 2017

Débora Dainez possui Graduação em Fonoaudiologia (2006) pela Universidade Metodista de Piracicaba. Em 2008, concluiu o mestrado em Educação no núcleo Práticas Educativas e Processos Interacionais do Programa de Pós-Graduação em Educação da mesma Universidade. Em 2014, conclui o doutorado pela Faculdade de Educação da Universidade Estadual de Campinas, na área Psicologia e Educação. Realizou uma pesquisa de pós-doutorado no Grupo de Pesquisa Pensamento e Linguagem da Faculdade de Educação da Universidade Estadual de Campinas. Trabalha na área da Educação, com especial interesse na questão do desenvolvimento humano. Tem participado na realização de projetos de investigação relacionado aos seguintes temas: linguagem, personalidade, relações de ensino, práticas escolares, deficiências, educação especial, educação inclusiva, perspectiva históricocultural. 